\begin{tabular}{|c|c|c|}
\hline \multirow[t]{3}{*}{$\mathbb{E}^{\mathrm{E}} \mathrm{M}_{\mathrm{S}}$} & KEMAS 15 (2) (2019) 160-170 & GEMAS \\
\hline & Jurnal Kesehatan Masyarakat & 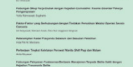 \\
\hline & http://journal.unnes.ac.id/nju/index.php/kemas & 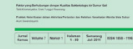 \\
\hline
\end{tabular}

\title{
Prediction Model and Scoring System in Prevention and Control of Stunting Problems in Under Five-Year-Olds in Indonesia
}

\author{
Demsa Simbolon ${ }^{\bowtie}$, Desri Suryani, Epti Yorita \\ Bengkulu Health Polytechnic Ministry of Health
}

\section{Article Info}

Article History:

Submitted February 2018

Accepted October 2019

Published November 2019

Keywords:

Stunting, LBW, maternal reproductive health, immunization, Fe tablets

DOI

https://doi.org/10.15294/

kemas.v15i2.13415

\begin{abstract}
Prevalence of stunting in Indonesia is a cause for concern. We used IFLS 2007 as secondary data in the cross-sectional study to develop a problem-solving and prevention model of stunting. The study was conducted in 2016 to predict a model from the characteristics, parents, and health care of the child. We recruited 3589 children under-five years from IFLS 2007 data as samples. The inclusion criteria are 1-5 years old children from 15-49 years old pregnant women, living with biological parents, available data of birth weight and gestational age, and do not have chronic disease. We used multiple logistic regression for modeling, and Receiver Operation Characteristic (ROC) Curve as a diagnostic test. We found that $39.5 \%$ of children under-five have stunting. Stunting protective factors are: prevention of LBW (Low Birth Weight) in infant, limitation of number of children by three, improved parenting for the boys, prevention of young-age pregnancy and stunting in the female adolescent. Other factors are completing immunization, improving maternal education and the health services of under-five children in rural areas, and improving Fe consumption for pregnant mothers. The model was able to prevent and delay the stunting in toddler by $64 \%$, with $61.9 \%$ sensitivity and $60.9 \%$ specificity, and AUROC $65.5 \%$. It is necessary to counsel the pregnant women with a low height and young-age pregnancy as a high risk, as well as management of the infant with LBW to prevent stunting.
\end{abstract}

\section{Introductions}

Stunting in toddler reflects a condition of failure to grow as a result of chronic nutrition insufficiency, so they become shorter for his/her age. It is a growth faltering situation caused by the accumulation of inadequate nutrition which occur since pregnancy until 24 months old (Hoffman et al., 2000; Bloem et al., 2013). Stunting is aggravated with imbalance catch up growth (Hoffman et al., 2000). The indicator of a stunted and severely stunted toddler is height-for-age or length-for-age by WHO-MGRS (Multicentre Growth Reference Study) (Picauly \& Toy, 2013; Mucha, 2013).
Whereas the definition of stunting, according to Indonesian Ministry of Health, is a toddler with $\mathrm{z}$-score $<-2 \mathrm{SD}$ (stunted) and $<-3 \mathrm{SD}$ (severely stunted) (Indonesian Ministry of Health, 2010). Stunting is a shared global nutritional problem, specifically in low-income and developed countries (UNICEF, 2013). It is turned to a universal problem because it related to increased risk of morbidity and mortality.

Globally, in 2010 there were 171 million stunting children, which 167 million of them were living in developed countries. The prevalence of stunting decreased from $39.7 \%$ in 1990 to $26 \%$ in 2010 . This trend is expected to 
reach $21.8 \%$ (142 million) in 2020 (Onis et al., 2012). Meanwhile, in Indonesia, the prevalence is still high, with a wide variation within each province. WHO (2010) stated that stunting would become a severe and serious health problem in the community if the prevalence is $30-39 \%$ and $\geq 40 \%$, respectively (WHO, 2010). The lowest prevalence number is Riau Islands, Yogyakarta Special Region, Special Capital Region of Jakarta, and East Kalimantan $(<30 \%)$, and the highest one is East Nusa Tenggara (>50\%). Basic Health Research (Riskesdas) 2013 showed that the national prevalence of stunting is $37.2 \%$, consisting of $18 \%$ severely stunted and $19.2 \%$ stunted children. The number is increasing compared to 2010 (35.6\%) and 2007 (36.8\%) (Balitbangkes, 2013).

The long-term effects of stunting in the individual and society are reduced cognitive and physical development, decreased productivity capacity, increasingly poor hygiene, and increasing the risk of degenerative disease such as diabetes mellitus. Moreover, onset of stunting of $<2$ years of age will cause low cognitive achievement in school-year age and adolescent. In 2025, it is estimated that the number of stunted toddlers is 125 million if there is no intervention for stunting (WHO, 2014). Several studies described that the effects of stunting were lower academic achievement (Picauly \& Toy, 2013), increase of the risk of obesity (Hoffman et al., 2000; Timaeus, 2012), more vulnerable in non-communicable disease, and increasing the risk of degenerative disease (Picauly \& Toy, 2013). One of the indicators of poverty is the prevalence number of stunting. Therefore, stunting is a predictor of inadequate human resources that will also affect nation potential development (UNICEF, 2013).

Many study in various countries found a multifactorial risk for causing stunting, such as short birth height, low-income family, low educated mother, and short family stature. A mother with short stature is likely to give birth to a short child. One study in Egypt showed that child born from a mother with $<150 \mathrm{~cm}$ height is prone to grow stunted (Zottarelli, 2007). Another study in Semarang stated that short stature of father and mother were a risk factor for stunting in 12-36 months old child (Candra, 2011). Stunting is also caused by infection and nutrient deficiency (Guerrant et al., 2009). A study at a slum area in Mexico described the protective factor of stunting was parenting (Reyes et al., 2004). Stunting can be prevented in children with exclusive care by his/ her mother. In contrast, children who live in a low-income family has greater risk to become stunted because of less nutrient fulfillment (Fernald, 2007). The prevalence number of stunting is increasing with the education of parents. The child with low educated mother and father is $22.56 \%$ dan $23.26 \%$, respectively, whereas in high educated mother and father is $13.81 \%$ dan $12.53 \%$ (Zottarelli et al., 2007). A study in North Maluku showed that the risk factors of stunting were child age and gender, the number of foods in family per day, income and job of a father (Ramli et al., 2009).

In Indonesia, the prevalence number of stunting is concerning. From 34 provinces, 14 of them was categorized into severe stunting, and 15 provinces were serious one (Balitbangkes, 2013). The period of 0-24 months and growing toddler are the golden period that determines his/her quality of life. Both are sensitive period in which any abnormality on this time cannot be corrected. Therefore, we need to prevent and counter stunting so that it is not continuing in his/her life. It is necessary to create a policy plan for stunting problem. In order to establish evidence-based policy plan, a model is built for preventing stunting. Our study aimed to (1) identify the prevalence of stunting in toddler based on multiple factors, such as mother, infant, and toddler condition; health services; and family condition which related to toddler stunting in Indonesia, (2) develop prediction model and scoring system of controlling and preventing toddler stunting in Indonesia as a health promotion media for optimal linear growth.

\section{Methods}

We used a cross-sectional study design in samples collected by sampling panel. IFLS (Indonesian Family Life Survey) or commonly known as SAKERTI (Survei Aspek Kehidupan Rumah Tangga Indonesia) was used as our data. The population was all livebirth children who born in $2002-2007$ and from reproductive mothers in the IFLS 2007 period. We recruited the toddler from IFLS 2007 data from $15-49$ 
years old mothers. The samples are collected with total sampling based on our inclusion criteria. We included a child who lived with his/her biological parents; birth weight and gestational age data were available; was $1-5$ years of age during IFLS 2007 and had no chronic disease. In total, we have 3597 toddlers as samples. The study setting is based on the IFLS 2007 research location. A structural questionnaire developed since 1993 and modified for IFLS 2007 was used for our data collection instrument. The first step of modeling and developing the scoring system was inventorizing the variables from IFLS 2007 questionnaire which was identified from household and individual questionnaire. The data analysis was conducted later on. A prediction model is identified from mother, infant, and toddler factor; health services; and family condition. We determined toddler growth failure according to Z-score calculated with WHO Anthro v.3.1.0 and WHO anthroPlus v.1.0.3 software. Next, we classified the nutrition status based on WHO anthropometry cut-off index (2006). The univariate analysis was conducted to test two relationships between each variable as a selection process for multivariate analysis, which used a double logistic regression model. According to the gained model, we developed a scoring system for early detection and eased daily application of stunting prevention and control. The diagnosis of the scoring system used Receiver Operation Characteristic (ROC) test to determine the cut-off point. Furthermore, the analysis of sensitivity (Se), specificity (Sp), positive predictive value (PPV), negative predictive value (NPV), and negative (NPN) based on cut-off scoring was created by using cross-table, where scoring was the gold standard and stunting were the test variable. The Area Under Curve (AUC) of ROC described the overall performance of a diagnostic test that was interpreted as average value of sensitivity test for all specificity test probability.

\section{Results and Discussions}

Table 1 illustrated that $41.1 \%$ of boys had linear growth abnormality, consisting of $16.8 \%$ who were severely stunted, and $24.3 \%$ who were stunted. Moreover, there were $37.8 \%$ of girls with growth abnormality, which consists of $15.8 \%$ severely stunted and $23.7 \%$ stunted. The total of abnormal linear growth in toddlers was $39.5 \%$.

Our result was different compared to Basic Health Research 2007, later on, it decreased in 2010 (35.7\%) and rose again in 2013 (37.2\%), which consists of $18 \%$ severely stunted toddler and $19.2 \%$ stunted toddler (Balitbangkes, 2013). The prevalence of stunted child in Indonesia varied from average to very high. The highest was East Nusa Tenggara (NTT) with $>50 \%$, and the lowest was Riau Islands. Only five provinces had $<30 \%$ prevalence: Riau Islands, Yogyakarta Special Region, Special Capital Region of Jakarta, East Kalimantan, and Bangka Belitung (Balitbangkes, 2013). Compared to other ASEAN countries, Indonesia was categorized as high prevalence group, similar to Cambodia and Myanmar (Bloem et al., 2013). Moreover, according to the World Health Statistics 2012, the global prevalence of stunting was $26.7 \%$ (WHO, 2012).

Figure 1 showed the linear growth abnormality (stunted or severely stunted) that occurred on all age groups. The abnormality proportion in 6-11 months old was $20.9 \%, 12$ -

Table 1. The Proportion of Linear Growth Abnormality Based on Gender

\begin{tabular}{|c|c|c|c|}
\hline Height-for-age index & $\begin{array}{l}\text { Male } \\
(\mathrm{n}=1831)\end{array}$ & $\begin{array}{l}\text { Female } \\
(\mathrm{n}=1756)\end{array}$ & $\begin{array}{l}\text { Total } \\
(\mathrm{n}=3587)\end{array}$ \\
\hline $\begin{array}{lll}\begin{array}{l}\text { Height-for-age } \\
\text { (mean } \pm \text { SD) }\end{array} & \text { index, } & \text { Z-score } \\
\end{array}$ & $-1.62 \pm 1.91$ & $-1.5 \pm 2.01$ & $-1.65 \pm 1.96$ \\
\hline \multicolumn{4}{|l|}{ Linear Growth Category } \\
\hline Severely Stunted $(\mathrm{n}=567)$ & 16.8 & 14.7 & 15.8 \\
\hline Stunted $(\mathrm{n}=849)$ & 24.3 & 23.0 & 23.7 \\
\hline Normal $(n=2048)$ & 55.5 & 58.7 & 57.1 \\
\hline Tall $(n=123)$ & 3.4 & 3.6 & 3.5 \\
\hline
\end{tabular}

Source : IFLS 2007 


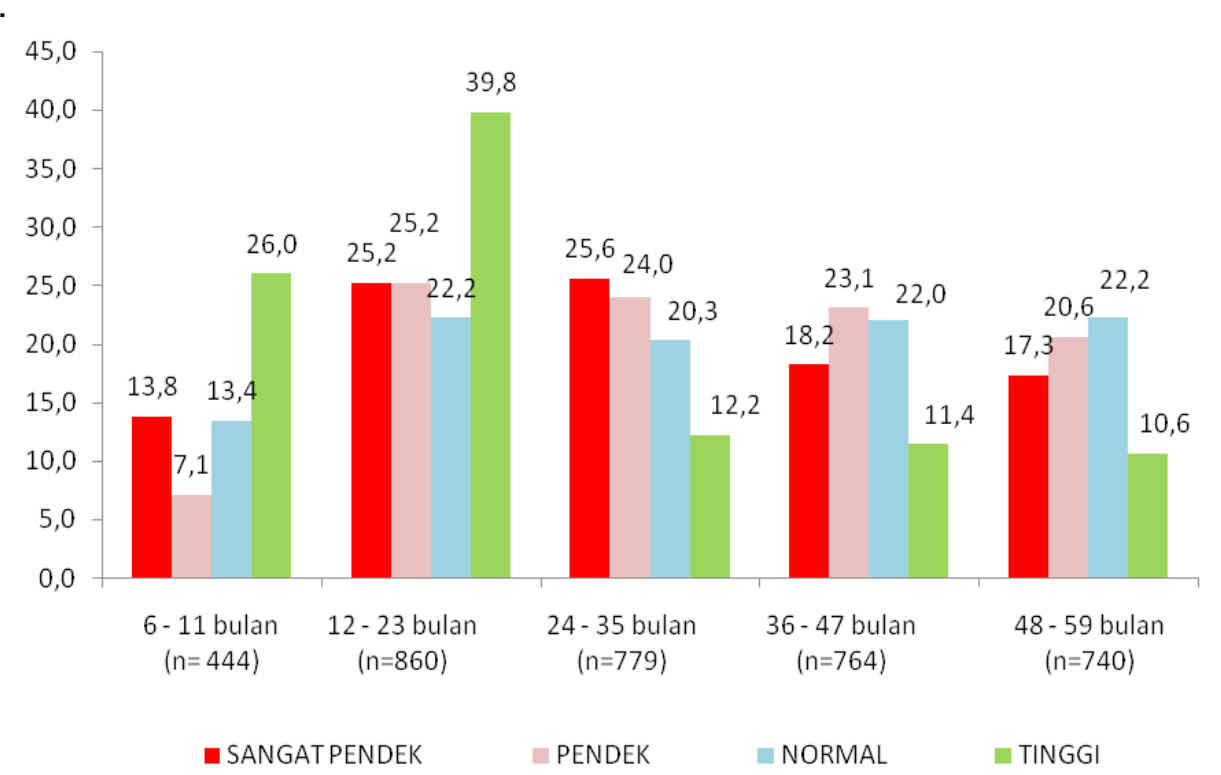

Source : IFLS 2007

Figure 1. The Proportion of Linear Growth Abnormality Based on Age Group

23 months was $50.4 \%$, 24-35 months was $49.6 \%$, and $48-59$ months was $37.9 \%$. In our study, the prevalence number is increasing, along with the older the toddler's age. It described that the prevalence was higher in 12-23 months and 2435 months of age. Riskesdas (2013) also stated the older the age, the higher the number of stunting. Based on Balitbangkes (2013), there were $24.9 \%$ stunted children in $0-5$ months of age, $28.5 \%$ in $6-11$ months, $38.6 \%$ in $12-23$ months, and $42 \%$ in $24-35$ months. The age of 12-24 months is a crucial period because the toddler was prone to infection or nutritional deficiency. It is a transition period between infant to toddler; one of significant change is shifting food, from breastmilk into solid food. The toddler may be difficult to be fed during the period. When they were already exposed to an unhealthy environment, they may also contracted a disease, especially infectious disease (Welasasih dan Wirjatmadi, 2012). Recurrent infection in a toddler is related to height abnormality. A study conducted in Pancatuba rural area of Brazil described the correlation between recurrent diarrhea and stature disruption. Toddlers who got diarrhea for the first 1-2 months of life may have height disturbance by 4-5 cm (Guerrant et al., 2009). Another study in Ethiopia found that the highest stunting prevalence was 13-24 months old toddler, and the lowest was 0-6 months of age. These findings described cumulative process, which started in the uterus and continuing until three years after birth. The first two years of life is considered as the critical period of the growth. During the period, the growth rate is faster than other age. In between birth and one year of age, the mean of infant length increased by $50 \%$ (Teshome et al., 2009).

Based on the model in Table 2, we needed to minimize number of LBW (Low Birth Weight) infant, limit to have three children, improved parenting for the boys, and prevented early age ( $<20$ years old) pregnancy. It was also necessary to improve adolescent's nutrition for optimize his/her height, completed immunization, increased mother's education, focused on health services of the toddler in a rural area, and increased iron tablet consumption for pregnant women. Overall, we could decrease $64 \%$ of stunting prevalence if we implemented the model.

The prediction model of prevention and control in Table 2 described that there 
Table 2. Prediction Model of Stunting Prevention and Control in Indonesian Toddler

\begin{tabular}{llllll}
\hline Variable & Category & $\mathrm{B}$ & $\mathrm{P}$ & $\mathrm{OR}(95 \% \mathrm{CI})$ & Scoring \\
\hline Birth Weight & $<2.9 \mathrm{~kg}$ & 0.693 & 0.0001 & $2.0(1.62-2.47)$ & 6 \\
& $2.9-3.2 \mathrm{~kg}$ & 0.346 & 0.001 & $1.41(1.14-1.74)$ & 3 \\
& $3.21-3.5 \mathrm{~kg}$ & 0.074 & 0.51 & $1.08(0.86-1.34)$ & 1 \\
& $>3,5 \mathrm{~kg}$ & & & 1 & 0 \\
Number of Child & $\geq 4$ children & 0.212 & 0.019 & $1.24(1.04-1.47)$ & 2 \\
& $1-3$ children & & & 1 & 0 \\
Gender & Male & 0.199 & 0.005 & $1.22(1.06-1.4)$ & 2 \\
& Female & & & 1 & 0 \\
Birth Age & $<20$ years old & 0.341 & 0.016 & $1.36(1.04-1.79)$ & 3 \\
& $>35$ years old & -0.257 & 0.04 & $0.82(0.68-0.99)$ & 0 \\
\multirow{5}{*}{ Mother's Height } & 20-35 years old & & & 1 & 0 \\
& $<148.2 \mathrm{~cm}$ & 0.998 & 0.0001 & $2.71(2.21-3.32)$ & 11 \\
& $148.2-151.4 \mathrm{~cm}$ & 0.517 & 0.0001 & $1.68(1.37-2.06)$ & 5 \\
& $151.5-154.9 \mathrm{~cm}$ & 0.267 & 0.012 & $1.31(1.06-1.61)$ & 2 \\
Immunization Status & $>154.9 \mathrm{~cm}$ & & & 1 & 0 \\
Incomplete & 0.287 & 0.0001 & $1.33(1.14-1.56)$ & 3 \\
Mother's Education & Complete & & & 1 & 0 \\
\multirow{3}{*}{ Residence } & Short & 0.419 & 0.0001 & $1.52(1.31-1.77)$ & 4 \\
& High & & & 1 & 0 \\
Fe tablet use & Rural & 0.236 & 0.002 & $1.27(1.09-1.46)$ & 2 \\
Constant & Urban & & & 1 & 0 \\
& $<90$ tablets & 0.192 & 0.009 & $1.21(1.05-1.39)$ & 2 \\
& $\geq 90$ tablets & & & 1 & 0 \\
& & -2.007 & & &
\end{tabular}

Overall percentage $=64 \%$

Source : IFLS 2007

are some factors that need to be prevented in order to tackle stunting problem in Indonesian toddlers, such as preventing LBW infant, limit to only having three children, good parenting for boys, and preventing $<20$ years old female to bear a child. Other factors are improving nutrition status in adolescent to maximize her height, completing immunization, improving mother's education, focusing health services for the toddler in a rural area, and increasing iron tablet supplement for pregnant women.

LBW is a major risk factor for stunting. The lower the birth weight, the higher the risk of stunting. The results of this study were in line with the results of a study in rural Malawi which found that the strongest predictor of stunting at 12 months was LBW (Espo et al., 2002). Some studies also proved that birth weight is associated with incidence of stunting in infants. Children born with low birth weight are more stunted than children with normal birth weight (Mardani et al., 2015). Children with low birth weight have a risk of 5.87 times to becoming stunted (Rahayuh et al., 2016). These showed that low birth weight had a large effect on stunting. In LBW children followed by inadequate food intake, poor health services, and the frequency of recurrent infectious diseases during the growth period results in delayed growth and produce stunting children (Mardani, 2015). Birth weight is a strong predictor of future body size determination. This was because babies who experience Intra Uterine Growth Retardation (IUGR) could not pursue normal growth during childhood (Barker, 2008). LBW babies experience growth retardation in the uterus, both acute and chronic (Akram and Arif, 2005). Most LBW babies experience growth disorders in childhood. In Asian countries, such as Bangladesh, China, India, Pakistan, the Philippines and Sri Lanka, the incidence of LBW can predict the nutritional state of children in the preschool period. The conclusion of the 12 studies that have been carried out revealed that IUGR (Intra Uterine Growth Retardation) baby experienced growth 
failure in the first two years of life. At the age of 17 to 19 years, men and women born with IUGR-LBW have a body height of $5 \mathrm{~cm}$ shorter and weigh $5 \mathrm{~kg}$ lower than children with normal birth weight (Allen and Gillespie, 2001).

Prediction models show that mothers with more than 3 parities risk 1.24 times of having stunted children. Parital status could tell the condition of the mother's womb which can project future pregnancy and the fetus. Mothers with first pregnancy or primipara are considered at risk, due to unpreparedness of the reproductive organs and mothers with pregnancies more than four (multipara) are said to be at risk due to weakening of reproductive organs from previous pregnancies (Luke and Brown, 2007). However, several studies actually proved that primipara was a risk factor for stunting. A study in Europe from April 1991 to December 1992 where 1335 infants were born, found that maternal parity had a large influence on the size of the body at birth. Babies born to primiparous mothers tend to be weigh lighter, shorter and have a smaller head circumference (Ong et al., 2002). The study of 1650 mothers and infants recorded in the Obstetrics and Gynecology Department at the University College London Hospital found that primiparous mothers had a lower birth weight babies than multiparous mothers and babies born from primiparous mothers were more likely to be born with $0.6 \mathrm{~cm}$ birth length shorter than babies born from multiparous mothers (Hindmarsh et al, 2002).

In this study, the prevalence of stunting was higher in boys (41.1\%) than girls $(31.8 \%)$, where boys risk of stunting is1.22 times greater (OR 95\% CI: 1.06- 1.4). In line with the 2013 Riskesdas data, the prevalence of stunting was more prevalent in boys $(38.1 \%)$ compared to girls (36.2\%) (Balitbangkes, 2013). Research in Tanzania based on Tanzania Demographic and Health Surveys 2010 data reported that the risk of stunting in boys aged 0-23 months was 1.66 (OR 95\%; 1.34-2.06) and boys aged 0- 59 months were 1.39 (OR 95\% 1.23-1.58) compared to girls (Chirande et al., 2014). Even in school age, in a cross-sectional study in Ethiopia showed that the prevalence of stunting in boys was higher than in girls (Zelellw et al., 2013). The mechanism of the higher risk of stunting for boys needs to be examined more deeply. During infancy and childhood, girls tend to be less likely to be short and very short than boys, besides, girls can survive in large numbers compared to male infants in several developing countries including Indonesia (Ramli et al., 2009).

Pregnancy at the age of less than 20 years was a risk factor for growth disorders in infants. Mothers who give birth at the age of less than 20 years had a risk of 1.36 times greater of having a stunting baby compared to mothers who give birth at the age of 20-35 years. The younger the age of the mother during childbirth the higher the prevalence of stunting. Pregnancy that occurs in adolescence was a risk factor for poor birth output and her own health. Pregnancy in adolescence is a public health problem as an indicator of sexual and reproductive health problems. In South Africa, pregnancy in adolescence causes problems due to undesirable pregnancies. Studies in the United States and the Netherlands have found that young teenage mothers are more likely to give birth to premature babies than women in twenties (Hogue et al., 2010).

Prediction models showed that short mothers are risk factors for stunting in infants. According to Riskesdas 2010 report, the prevalence of short children tends to be higher for mothers with a height of $<150 \mathrm{~cm}(46.7 \%)$ compared to mothers with a height of $>150$ $\mathrm{cm}(34.8 \%)$. Research in China found that mothers with height $<155 \mathrm{~cm}$ were more at risk of having stunted children (Yang et al., 2010). In Egypt, children born to mothers with a height of less than $150 \mathrm{~cm}$ were more at risk for stunting (Zottarelli et al., 2007). The mother's posture also reflects the mother's height and initial environment which will contribute to the child's height as an independent factor (Taguri et al., 2009). Mothers with short stature are also a factor that must be prevented to overcome stunting. In developing countries, the problem of LBW and IUGR begin with slowing or retardation of fetal growth due to malnutrition in pre-pregnancy and pregnant women. The condition of IUGR is almost half related to maternal nutritional status, namely body weight of pre-pregnant women that is not in accordance with the mother's height or short 
stature, and weight gain during pregnancy is less than the recommendation. Mothers who were short at 2 years of age tend to be short as teenagers and adults. Maternal nutrition and health status is very important as a determinant of stunting. A malnourished mother is more likely to give birth to obstructed children, perpetuating the vicious cycle of nutrition and poverty (UNICEF, 2013). If mothers with short stature are pregnant, mothers are at risk of giving birth to LBW babies. Short pregnant women limit uterine blood flow and growth of the uterus, placenta and fetus so that they will be born with a low body weight. If there is no effort to improve the nutritional status of young women and pregnant women, the risk of babies born IUGR and LBW will continue in the next generation resulting in intergenerational short child problems (UNICEF, 2013; Sari et al, 2010).

The prevalence of stunting in infants with incomplete immunization was $41.1 \%$ higher than in children with complete immunization (32.5\%), with a risk of 7 times (95\% OR: 1.256-42.014). Research in Kupang, East Sumba, NTT and Banda Aceh City also found that incomplete basic immunization was a risk factor for stunting. Children who did not have a history of immunization have a greater chance of stunting than children with history of immunization. Children who had no immunization are at risk of developing an infectious disease, and if the child has a history of infection, increase in the incidence of stunting will follow (Picauly and Toy, 2013; Rahmad and Miko, 2016). Girma and Genebo (2007) explained that infection inhibits normal immunological reactions by depleting the body's energy. If toddlers do not have immunity against disease, then toddlers will lose energy more quickly due to infectious diseases, as the first reaction due to infection is a decrease in appetite so that children refuse food given by their mothers. Rejection of food means reduced intake of nutrients in a child's body (Anhari, 2008). This shows the importance of completing immunizations. Immunization will give the body immunity to illness by putting antigen in the body so that the body is resistant to diseases that is endemic or dangerous for someone. Severe infections can aggravate nutritional conditions through disruption of food intake and remind them of losing the body's essential nutrients through vomiting and diarrhea. In addition, infectious diseases such as respiratory infections can also reduce appetite. Conversely, malnutrition, although mild, has a negative effect on the body's resistance and infection.
Prediction models showed that low maternal education was a risk factor for growth disorders. Study in Kupang NTT also showed that lower educated mothers had a greater chance of having stunting children than highly educated mothers. If maternal education is high, it will be followed by a decrease in the incidence of stunting by 3 times compared to those with low education (Picauly and Toy, 2013). Some studies have found that formal education levels and knowledge of maternal nutrition are very influential on the chances of stunting. Parents with higher levels of education have the opportunity to get a better job, which in turn will have an impact on income and food availability for their families. Parental education is also related to knowledge of nutrition and parenting (Oemat et al., 2013). This shows that maternal education and knowledge needs to be improved, because stunting was a chronic process due to long lasting malnutrition problem such as poverty and inappropriate parenting because of the mother's ignorance of nutrition due to low education. As a result, infants and toddlers often suffer recurrent disease due to poor hygiene and sanitation (Nadiyah et al., 2014).

The stunting prevalence in rural areas is higher (45\%) than in urban areas (35.3\%). Toddlers in rural areas are 1.27 times at greater risk of stunting compared to toddlers in urban areas. Some results of the study found that area of residence was significantly associated with the incidence of stunting in infants (Taguri et al., 2009). The high risk of disruption of growth in toddlers in rural areas is estimated to be related to low access to health facilities for monitoring growth and control of children under five when experiencing illness. The low access resulted in the nutritional status of children under five being less well monitored. Attendance to Integrated Care Post (Posyandu) is an indicator of the reach of health services for children under five. The presence and activeness of toddlers to the Posyandu has a profound effect on monitoring of nutritional status. Every month toddlers will get weight weighing services, supplementary feeding and nutritional counseling. Toddlers who are routinely weighed and measured every month will find out about changes in nutritional 
Table 3. Test of Stunting Determination Scoring System in Toddlers

\begin{tabular}{|c|c|c|c|c|}
\hline \multirow[b]{2}{*}{ Scoring system } & \multicolumn{2}{|l|}{ Stunting } & \multirow[b]{2}{*}{$\mathrm{p}$} & \multirow{2}{*}{$\begin{array}{l}\text { OR } \\
(95 \% \mathrm{CI})\end{array}$} \\
\hline & $\begin{array}{l}\text { Yes } \\
(\mathrm{n}=2171)\end{array}$ & $\begin{array}{l}\text { No } \\
(\mathrm{n}=1416)\end{array}$ & & \\
\hline $\begin{array}{l}\text { Score }>13.5 \\
\text { Score } \leq 13.5\end{array}$ & $\begin{array}{l}876 \\
1323\end{array}$ & $\begin{array}{l}848 \\
540\end{array}$ & 0.0001 & $2.53(2.2-2.9)$ \\
\hline
\end{tabular}

Sensitivity 61.9\%, Specificity 60.9\%, AUROC score 65.5\%

Source : IFLS 2007

status (Welasasih and Wirjatmadi, 2012). Health services have an effect on health by the rapid handling of health problems, especially nutrition problems. Services that are always ready and close to the community will be very helpful in improving health status.

Consumption of iron supplement tablets of less than 90 tablets during pregnancy was a risk factor for stunting. The results of the study found $42 \%$ of children under five stunting occurred in infants born to mothers consuming iron tablets less than $90 \%$, whereas in mothers who consumed more than 90 tablets, there were $35.5 \%$ of children under five experiencing linear growth disorders. The relationship of consumption of $\mathrm{Fe}$ tablets to toddlers' linear growth disorders through the mechanism that anemic pregnant women are at risk of giving birth to babies who experience growth disorders in the uterus. Hemoglobin level is a biochemical indicator to determine the nutritional status of pregnant women. In a normal pregnancy there is a slight decrease in hemoglobin concentration due to hypervolemia which occurs as a physiological adaptation in pregnancy. Anemia that occurs during pregnancy is one of the major problems that occur in many developing countries, including Indonesia. The results of Simbolon's study (2013) found that there were differences in the average birth weight of babies ranging from 440.7 grams heavier in pregnancies without anemia. Anemic pregnant women are at 6.4 times greater risk of giving birth to a LBW baby. Severe anemic pregnant women are at risk of experiencing maternal and neonatal morbidity and mortality, the possibility of giving birth to LBW and premature babies is also greater as well as abortion and congenital defects. Iron deficiency can cause interference or obstacles to the growth of the fetus in both body and brain cells. Physiologically, a decrease in hemoglobin levels during pregnancy occurs due to an imbalance in the number of red blood cells and blood plasma. Imbalance results in a decrease in hemoglobin levels (Bondevik, 2001).

Scoring in table 4 for each risk factor that must be prevented and addressed based on the ratio of the prevalence of each variable. The steps to form scoring begin (1) determine many classes (12 classes), (2) determine the scoring based on the value of the odds ratio. Determination of the number of scoring based on the odds ratio of each variable. Based on the scoring on each variable, we conducted a trial of 3587 respondents. The total score of all variables from each respondent was categorized based on the ROC curve so that the Cut-off point was obtained to assess the success of prevention of stunting. The obtained Cut-off Point is $>13.5$ with a sensitivity value of $61.9 \%$ and specificity of $60.9 \%$, AUROC value of $65.5 \%$.

\section{Conclusions}

The prediction model shows that the risk factors associated with stunting for children are birth weight, parity, gender, age of mother at delivery, maternal height, immunization completeness, maternal education, family residence and the number of iron supplement tablets consumed by the mother during pregnancy. The dominant risk factors associated with stunting are severe LBW and short mothers. Stunting intervention efforts are focused on improving modifiable risk factors. The scoring method obtained Cut-off Point> 13.5 as a detection of stunting risk with a sensitivity of $61.9 \%$, specificity of $60.9 \%$, value of Area Under the Curve 65.5\%. This model is recommended to predict stunting in infants in Indonesia. The government needs to make efforts to plan, prevent, promote and intervene specifically in stunting prevention, such as 
assisting pregnant women with low height and adolescence as a high-risk group and prevention and management of babies born with LBW to prevent stunting. Special attention to lower education mothers through increasing knowledge by optimizing the class of pregnant women, health monitoring in pregnant women with high parity. Increasing access to health services for infants living in rural areas so that children get complete basic immunization and pregnant women consume enough iron supplement tablets.

\section{Acknowledgements}

We thank RAND Corps (Research and Development), a non-profit organization established in 1946 and headquartered in Santa Monica, California. This institution is engaged in the field of research and analysis to assist the state in improving policy and decision making. IFLS data is public domain data and can be downloaded for free at http://www.rand. org. The writing of this research report was funded from the BOPTN Health Polytechnic of Bengkulu. A big thank you to the Bengkulu Ministry of Health Polytechnic expert team for providing advice and guidance from the beginning of the proposal to the writing of the research report. Thank you also to the research team who contributed to completing this research article.

\section{References}

Akram, D.S., Arif, F. 2005. Ponderal Index of Low Birt Weigt Babies a Hospital Based Study. The Journal of the Pakistan Medical Association, Juni 2005, 55 (6), 229-231

Allen, L dan Gillespie, S. 2001. What Works? A Review of the Efficacy and Effectiveness of Nutrition Interventions. United Nations Administrative Committee on Coordination Sub-Committee on Nutrtition. Asian Development Bank (ACC-SCN). Geneva in collaboration with the Asian Development Bank, Manila.

Badan Penelitian dan Pengembangan Kesehatan Departemen Kesehatan RI. 2013. Laporan Hasil Riset Kesehatan Dasar 2013. Jakarta.

Barker, M.D. 2008. Nutrition In The Womb. The Barker Foundation. USA.

Bloem, M.W., Pee, S.D., Hop, L.T., Khan, N.C, Laillou, A., Minarto, Pfanner, R.M., Soekarjo, D., Soekirman, Solon, J.A., Theary, C., Wasantwisut, E., 2013. Key strategies to further reduce stunting in Southeast
Asia: Lessons from the ASEAN countries workshop. Food and Nutrition Bulletin, (supplement) 2013, 34 (2), 8-16

Bondevik, G.T., Lie, R.T., Ulstein, M. 2001. Maternal Hematological status and risk of low birth weight preterm delivery in Nepal. Acta Obstetricia Gynecologica Scandinavica 80 (5), 402-408.

Candra, A., Puruhita, N., Susanto, J.C. 2011. Risk Factors of Stunting among 1-2 Years Old Children in Semarang City. Media Medika Indonesia; 45 (3): 206-212.

Chirande, L., Charwe, D., Mbwana, H., Victor, R., Kimboka, S., Issaka, S.I., et al. 2015. Determinants of stunting and severe stunting among under-fives in Tanzania:evidence from the 2010 cross-sectional household survey. BMC Pediatrics2015, 15 (165), 1-13.

Espo, M., Kulmala, T. Maleta, K. Cullinan, T., Salin, M.L., Ashorn, P. 2002. Determinants Of Linear Growth And Predictors Of Severe Stunting During Infancy In Rural Malawi. Acta Paediatr, Desember 2002, 91 (12): 13641370.

Fernald, L.C., Neufeld, L.M,. 2007. Overweight With Concurrent Stunting In Very Young Children From Rural Mexico: Prevalence And Associated Factors. European Journal of Clinical Nutrition, 2007, 61 (5): 623-632.

Girma, W., Genebo, T., 2007. Determinants of Nutritional Status of Women and Children in Ethiopia. ORC Macro, Calverton, Maryland, USA.

Guerrant, R.L., Oriá, R.B., Moore, S.R., Oriá, M.O.B., and Lima, A.M. 2009. Malnutrition as an enteric infectious disease with longterm effects on child development. Nutr Rev. September 2009, 66 (9): 487-505.

Hindmarsh, P.C., Geary, M.P.P., Rodeck, C.H., Kingdom, J.C.P., Cole, T.J. 2002. Intrauterine Growth And Its Relationship To Size And Shape At Birth. Journal of the Pediatric Research. 52 (2). 263-268.

Hoffman, D.J., Sawaya, A.L., Verreschi, I., Tucker, K.L., Roberts, S.B. 2000. Why are nutritionally stunted children at increased risk of obesity? Studies of metabolic rate and fat oxidation in shantytown children from São Paulo, Brazil. Am J Clin Nutrition 72 (3),702-707.

Hoque, M. and Hoque, S. 2010. A comparison of obstetrics and perinatal outcomes of teenagers and older women: Experiences from rural South Africa African. Journal of Primary Health Care \& Family Medicine; 2 (1): 2-5.

Luke, B. \& Brown, M.B. 2007. Elevated Risk Of 
Pregnancy Complications And Adverse Outcomes With Increasing Maternal Age. European Society Of Human Reproduction And Embryology: 22 (5): 1264-1271.

Mardani, R.A.D., Wetasin, K., dan Suwanwaiphatthana, W. 2015. Faktor Prediksi yang Mempengaruhi Terjadinya Stunting pada Anak Usia di Bawah Lima Tahun. Jurnal Kemas, 11 (1):1-7.

Mucha, N. 2012. Implementing Nutrition-Sensitive Development: Reaching Consensus. Briefing paper November 2012, 20.

Nadiyah, Briawan, D., Martianto, D. 2014. Faktor Risiko Stunting Pada Anak Usia $0-23$ Bulan Di Provinsi Bali, Jawa Barat, dan Nusa Tenggara Timur. Jurnal Gizi dan Pangan Juli 2014, 9 (2), 125-132.

Oematan G \& Aspatria U. 2013. Faktor-Faktor Penentu Kejadian Gizi Buruk Stunting Di Daerah Dengan Karakteristik Pertanian Lahan Kering Kabupaten Kupang. Provinsi Nusa Tenggara Timur, Jurnal Pangan, Gizi, Dan Kesehatan; 5(1): 725-736.

Ong, K.K.L., Preece, M.A,. Emmett, P.M., Ahmed, M.L., and Dunger, D.B. 2002. Size at Birth and Early Childhood Growth in Relation to Maternal Smoking, Parity and Infant BreastFeeding: Longitudinal Birth Cohort Study and Analysis. Pediatric Research, 52 (6), 863867.

Onis M, Monika B, Borghi E, 2012. Prevalence and trends of stunting among pre-school children,1990-2020, Public Health Nutrition; 15 (1): 142-148.

Picauly I dan Toy SM. 2013. Analisis Determinan Dan Pengaruh Stunting Terhadap Prestasi Belajar Anak Sekolah di Kupang dan Sumba Timur, NTT. Jurnal Gizi Dan Pangan, Maret 2013, 8 (1), 55-62.

Rahayuh, A., Yulidasari, F., Putri, A.O., Rahman, F., Rosadi, D. 2016. Faktor Risiko yang berhubungan dengan Kejadian Pendek pada anak usia 6-24 bulan. Jurnal Kemas; 11(2): 96-103

Ramli, Kingsley EA, Inder KJ, Bowe SJ, Jacobs J, \& Dibley MJ. 2009. Prevalensi And Risk Factors For Stunting And Severe Stunting Among Under Five In North Maluku Province Of Indonesia. BMC. Pediatrics; 9 (64): 1-10. doi:10.1186/1471-2431-9-64

Reyes H, Pérez-Cuevas R, Sandoval A, Castillo R, Santos JI, Doubova SV et al. 2004. The Family as A determinant of stunting in children living in conditions of extreme poverty: a case-control study. BMC Public Health 2004, 4 (57): 1-10.
Sari, M., Dee, S.D., Bloem, M.W., Sun, K., Thorm, L., Moench, P.R. 2010. Higher household expenditure on animal source and nograim foods lowers the risk of stunting among children 0-59 months old in Indonesia. Implications of rising food prices. The Journal of Nutrition, 140:196-200.

Simbolon, D. 2013. Kehamilan Usia Remaja Prakondisi Dampak Status Gizi Terhadap Berat Lahir Bayi Di Kabupaten Rejang Lebong Propinsi Bengkulu). Prosiding Seminar Nasional Kependudukan. Jember, Fakultas Kesehatan Masyarakat Universitas Jember 16 Nopember 2013.

Taguri, A.E., Betilmal, I., Mahmud, S.M., Monem, A. A., Goulet, O., Galan, P., Hercberg, S. 2009. Risk Factor For Stunting Among UnderFives In Libya. Public Health Nutrition; 12(8), 1141- 1149. 12(8):1141-9.

Teshome. B., Kogi-Makau, W., Getahun, Z. \& Taye, G. 2009. Magnitude and determinants of stunting in children under five years of age in food surplus region of Ethiopia. The case of West Gojam Zone. Ethiopian Journal of Health Development; 23 (2): 98-106.

Timæus, I.M., 2012. Stunting and obesity in childhood: are assessment using longitudinal data from South Africa, International Journal of Epidemiology; 41: 764-772.

UNICEF, 2013. Improving Child Nutrition The achievable imperative for global progress. United Nations Publications Sales No.: E.13. XX.4.

Welasasih, B dan Wirjatmadi, R. 2012. Beberapa Faktor Yang Berhubungan Dengan Status Gizi Balita Stunting. The Indonesian Journal of Public Health; 8 (3): 99-104.

World Health Organization (WHO). 2012. World Health Statistics. Geneva: World Health Organization.

World Health Organization (WHO). 2010. Nutrition landscape information system (NLIS) country prfile indicators: intrepretation guide. Geneva: World Health Organization.

World Health Organization (WHO). 2014. Global Nutrition Targets 2025. Stunting Policy Brief. 14 (3)

Yang, X.L., Ye, R.W., Zheng, J.C., Jin, L., Liu, J.M., Ren, A.G. 2010. Analysis on Influencing Factors for Stunting and Underweight among Children Aged 3-6 Years In 15 Counties Of Jiangsu And Zhejiang Provinces. Zhonghua Liu Xing Bing Xue Za Zhi; 31 (5): 506-509.

Zelellw, D.A., Gebreigziabher, B.G., Alene, K.A. Negatie, B.A and Kasahune, T.A. 2014. Prevalence and Associated Factors of 
Demsa Simbolon, et al / Prediction Model and Scoring System in Prevention and Control of Stunting Problems

Stunting Among Schoolchildren, in Debre

Markos Town and Gozamen Woreda, East

Gojjam Zone, Amhara Regional State,

Ethiopia. Journal of Nutrition \& Food

Sciences, S8: 007:1-5.
Zottarelli, L.K., Sunil, T.S., Rajaram, S. 2007. Influence of Parental and Socioeconomics Factors on Stunting in Children Under 5 Years in Egypt. Eastern Mediterranean Health Journal; 13 (6): 1330- 1342. 